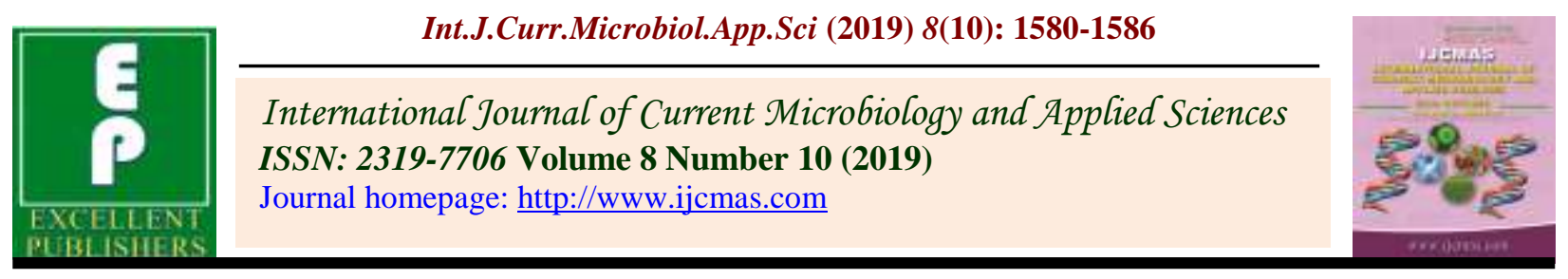

Review Article

https://doi.org/10.20546/ijcmas.2019.810.184

\title{
Forms of Potassium in Soil and their Relationship with Soil Properties- A Review
}

\author{
Harpreet Kaur*
}

Department of Soil Science, College of Agriculture, Punjab Agricultural University, India

*Corresponding author

Keywords

Exchangeable K, Forms of K, Non exchangeable $\mathrm{K}$,

Total K and Water soluble K

Article Info

Accepted:

12 September 2019

Available Online:

10 October 2019

\section{A B S T R A C T}

Potassium $(\mathrm{K})$ is vital to many plant processes and the knowledge about different forms and availability of potassium is must while studying the response of crops to $\mathrm{K}$. Because Potassium supply to crop plants is a complex phenomenon involving relationships among various $\mathrm{K}$ fractions in soil. Potassium is available in the soil in different forms and amount viz., water soluble $\mathrm{K}$, exchangeable $\mathrm{K}$, fixed $\mathrm{K}$ and mineral $\mathrm{K}$. Plants utilize not only the readily available $\mathrm{K}$ but also the non-exchangeable and mineral $\mathrm{K}$ during the crop growth. The potassium availability to plants is determined by the rate of change in the dynamic equilibrium between different forms of $\mathrm{K}$ in the soil which in turn is controlled by the mineral make up, rate of weathering and exchange properties of the soil. The distribution of different forms of $\mathrm{K}$ in soils is related to a number of soil properties such as soil minerals, particle size distribution, organic matter and $\mathrm{pH}$. The relationship between $\mathrm{K}$ forms and soil properties can be used to predict $\mathrm{K}$ availability in soil.

\section{Introduction}

There are four different forms of potassium in soils. These forms are water soluble, exchangeable, non exchangeable and mineral form of potassium in soils. These forms are not homogeneously distributed in soils but all these forms are in dynamic equilibrium with each other. The potassium dynamics in soil based on the magnitude of equilibrium among various forms of potassium and generally controlled by the physicochemical properties of soil. The amount of these fractions in soil depends on degree of weathering, parent material, $\mathrm{K}$ gains through manures and fertilizers and losses due to erosion, leaching and crop removal. However in the soil, the amounts of non-exchangeable and total fraction are high as compared to water soluble and exchangeable fraction. About $98 \%$ of total $\mathrm{K}$ which forms the bulk of soil potassium generally having primary (micas and 
feldspars) and secondary (illite group) clay minerals as unavailable forms. Water soluble and exchangeable $\mathrm{K}$ represents as readily available to plants, whereas non-exchangeable form of $\mathrm{K}$ regarded as slowly available form. Therefore, soil solution and exchangeable forms of $\mathrm{K}$ are usually readily available to plants. To confirm the availability of potassium in plants, it is required to determine the content of different forms of $\mathrm{K}$ in soil. The availability of $\mathrm{K}$ to plants is affected by the equilibrium, which is controlled by the rate of weathering of the minerals, complex mineralogical factors and exchange properties of the soil.

\section{Water soluble $\mathbf{K}$}

Potassium present in soil solution as soluble cation is termed as water soluble $\mathrm{K}$ which is readily absorbed by the plants and relatively unbound by cation exchange forces and invariably subject to leaching losses in relation to soil properties (Ramamoorthy and Velayutham, 1976). Appreciable quantities of potassium is likely to occur when applying water soluble $\mathrm{K}$ fertilizers and from irrigation water of high $\mathrm{K}$ content or soils contain high mixed soluble salts. In intensively cultivated soils of India, the water soluble $\mathrm{K}$ content is 0.2 per cent of the total $\mathrm{K}$ in surface soils indicating almost negligible contribution to the total potassium of soils. (Tandon and Sekhon, 1998) and it ranged from 4 to 125.6 $\mathrm{mg} \mathrm{kg}^{-1}$ in the soils of India. Generally surface soils had relatively high water soluble $\mathrm{K}$ than the subsurface soils. The possible reason for this could be an upward translocation of $\mathrm{K}$ by capillary rise (Sharma et al., 2009) and also could be due to vegetation, release of labile $\mathrm{K}$ from organic residues and addition of farmyard manure (Ranganathan and Satyanarayana, 1980). The water soluble K is positively correlated with clay and silt and negatively correlated with sand (Basumatary and Bordoloi, 1992). Hence soils contain high amount of clay content has more the water soluble K. In addition Srinivasarao and Takkar (1997) also stated that soils with larger amounts of clay showed greater amounts of water soluble and ammonium acetate extractable $\mathrm{K}$ in both the rhizosphere as well as non rhizosphere. The negative relationship between water-soluble $\mathrm{K}$ and sand content with greater amount of water-soluble $\mathrm{K}$ being present in heavy textured soils (Darunsontaya et al., 2012). Jatav and Sud (2006) observed that water-soluble $\mathrm{K}$ was significantly correlated with organic carbon.

\section{Exchangeable K}

The exchangeable potassium is the form of $\mathrm{K}$ held in the solid phase of soil, on clay and organic matter in the soil matrix, by electrostatic forces and easily moves into the soil solution as this form can be readily exchanged by other cations and also is readily available to plants. Exchangeable potassium is not homogeneously distributed on soil colloids (Mengel and Haeder, 1973). It constitutes approximately 90 per cent of the available form of potassium. Exchangeable $\mathrm{K}$ contribution towards total $\mathrm{K}$ is less than 2 per cent (Schroeder, 1974). The exchangeable $\mathrm{K}$ is important in replenishing soil solution potassium which is removed by cropping or lost by leaching. Baruah et al., (1991) revealed that exchangeable $\mathrm{K}$ is closely correlated with $\mathrm{pH}, \mathrm{CEC}, \mathrm{OC}, \mathrm{CaCO} 3$ and clay content. Singh et al., (1985) observed that the finer particles contained higher amount of exchangeable potassium as compared with coarse fractions because ammonium acetate $\mathrm{K}$ was positively correlated with per cent clay and silt and negatively with sand. But Srinivasarao et al., (2007) found that lower levels of exchangeable $\mathrm{K}$ were found in Inceptisols and Aridisols despite of greater content of K-rich mica in these soils attributes to lesser mobility of $\mathrm{K}$ from illite clay structure to the exchange complex because these minerals typically have 
a restrictive interlayer space which is selective for $\mathrm{K}$ ions, resulting in its low desorption (Sparks and Huang, 1985; Sparks 1987). In neutral and slightly alkaline soils, the $\mathrm{Ca}^{2+}$ ion is the dominating ion which causes the opening of clay mineral structure and promotes the release of lattice $\mathrm{K}$. The exchangeable $\mathrm{K}$ used for making fertilizer recommendation to the crops as it could give a better indication of the potential $\mathrm{K}$ supplying power of a soil (Sharpley, 1989).The higher amount of exchangeable $\mathrm{K}$ content was found in the surface soils than the subsurface soils attributed to the addition of $\mathrm{K}$ through manures, fertilizers and plant residues (Sharma et al., 2009). Guzel et al., (2006) indicated that exchangeable $\mathrm{K}$ was significantly and positively correlated to organic matter and clay content, indicating that as the amount and surface area of exchange complex increases the exchangeable $\mathrm{K}$ increases. Ngwe et al., (2012) found that there was significant and positive correlation between exchangeable $\mathrm{K}$ and organic matter.

\section{Non-exchangeable K}

Non-exchangeable $\mathrm{K}$ differs from mineral $\mathrm{K}$ because it is not bonded within the crystal structures of soil mineral particles. Generally, it is held at inter-lattice positions and this form is not exchangeable by NH4OAc (Ramamoorthy and Velayutham, 1976). The non exchangeable form of $\mathrm{K}$ is present largely within clay minerals and become available to plants with relatively difficulty. However it is in equilibrium with available forms and consequently acts as an important reservoir of slowly available K (Perkins, 1973). The rate and amount of non exchangeable $\mathrm{K}$ governs the inherent $\mathrm{K}$ status of a soil. Dhillon et al., (1985) revealed that the pattern of nonexchangeable $\mathrm{K}$ at different depths and found that it was higher in sub-surface soils compared to the surface soils. This might be due to release of fixed $\mathrm{K}$ to compensate the removal of water-soluble $\mathrm{K}$ and exchangeable $\mathrm{K}$ by plants. The higher amount of nonexchangeable $\mathrm{K}$ fraction in sub-surface layers is related to per cent clay and silt which could easily fix the potassium particularly in the soils rich in illitic clay minerals (Sharma et al., 2009). The per cent utilization of fixed $K$ decreased as the level of added $\mathrm{K}$ increased to rice crop (Ramanathan, 1978; Nagarajan, 1980).In the soils of north-west India, fixed K is the principal source for supplying $\mathrm{K}$ to plants (Pasricha, 2002). The net release of non-exchangeable $\mathrm{K}$ which is mainly interlayer $\mathrm{K}$ of clay mineral depends on the low concentration of potassium in soil (Martin and Sparks, 1983). The contribution of non exchangeable $\mathrm{K}$ to crops was relatively more in untreated plots than those receiving fertilizers $\mathrm{K}$ and there was close relationship between $\mathrm{K}$ in crops and non exchangeable $\mathrm{K}$ released from the soil (Ganeshamurthy and Biswas, 1985). The non exchangeable $\mathrm{K}$ is significantly correlated with per cent silt and clay of soil and its amount in the soil depends on the types and quantities of clay minerals, particle-size distribution, and removal of $\mathrm{K}$ from minerals (Das et al., 1993).

A significant and positive correlation of nonexchangeable $\mathrm{K}$ was found with the sand content of soils. Dixit et al., (1993) found that among the different soil separates, sand fraction was negatively correlated with nonexchangeable Baruah and Nath, (1992) and Pal and Mokhopadhyay, (1992) revealed that non-exchangeable $\mathrm{K}$ was significantly correlated with silt and clay content of soil. Basumatary and Bordoloi, (1992) reported that non-exchangeable potassium showed a positive correlation with clay, organic carbon content and CEC. This might be due to the fact that with an increase in organic matter in soils, the clay-humus complex becomes more active thereby, providing more exchange sites and access to potassium. 


\section{Lattice K}

It is fraction of $\mathrm{K}$ that gets fixed in lattice space of the 2:1 clay minerals. The lattice $\mathrm{K}$ constitutes from 93.60 to 94.95 per cent of the total $\mathrm{K}$ in different soils. The percent contribution of lattice $\mathrm{K}$ towards total $\mathrm{K}$ for surface soil was ranged from 94.78 to 95.27 with a mean value of 94.92. However, in case of subsurface soil such contribution of lattice $\mathrm{K}$ towards total $\mathrm{K}$ was ranged from 94.66 to 95.21 per cent, with a mean value of 94.84 per cent (Kundu et al., 2014). The lattice $\mathrm{K}$ is diffirent from mineral $\mathrm{K}$ because it is not bonded covalently within the crystal structure of soil mineral particle but held between adjacent tetrahedral layers of dioctahedral and trioctahedral wedge zones of weathered micas and vermiculite (Sparks, 1987). The large amount of lattice $\mathrm{K}$ indicates that the soils are rich in K-bearing minerals (Mukhopadhyay and Datta, 2001). The availability of lattice $K$ to plants depends on weathering, environmental conditions and soil texture (Grewal and Kanwar, 1973). The release and fixation of the lattice $\mathrm{K}$ is mainly depends on the soil reaction, type of clay minerals and type of cation etc. Fairly high content of lattice $\mathrm{K}$ indicates that these soils have been developed from mica-rich parent material and much of potassium is present in the micalattice (Mishra et al., 1993).

\section{Mineral K}

Most of the total $\mathrm{K}$ in soils is in the form of mineral $\mathrm{K}$ in a fixed or non-exchangeable form, mainly as $\mathrm{K}$-bearing primary minerals such as biotite, muscovite and feldspar. Most of the mineral $\mathrm{K}$ was present as $\mathrm{K}$ feldspar in the sand fractions. In general more than 90 per cent of the total $\mathrm{K}$ in the soils is found in mineral form as structural K (Pasricha, 2002). Sharma et al., (2009) also opined the dominance of this form over the other forms of $\mathrm{K}$ because the per cent contribution of mineral $\mathrm{K}$ to total $\mathrm{K}$ in soils was more than 90 per cent. They further revealed that the highest amount of mineral $\mathrm{K}$ was found in sub-surface soils than the surface soils. This may be because of the intense weathering of $\mathrm{K}$ minerals at the surface than the subsurface. Sharpley (1989) revealed that mineral K was a function of clay content of soil $\left(\mathrm{r}^{2}\right.$ of 0.66 to 0.90). Sidhu and Dhillon (1985) found that biotite, muscovite, microcline and orthoclase are the $\mathrm{K}$ bearing minerals present in sand fractions. Micas, orthoclase and microcline occurred in silt, while illite was found in clay fractions.

\section{Total potassium}

The total potassium in soil occurs as structural component of soil minerals and is unavailable to plants. The content of total potassium depends on the type of soil fraction, type of primary and secondary and type of parent material (Dhakad et al., 2017). Ahmed and Walia, (1999) revealed that the total K was found more in sub-surface soils than the surface soils. Clay mineralogy is a key factor affecting dynamics of $\mathrm{K}$ in the soils (Ghiri and Abtahi, 2011). Total K has highly significant and positive correlation with clay $\left(r=0.83^{*}\right)$ fraction showing that most of the Total- $\mathrm{K}$ is derived from interlayer of clay structure and increase total-K with finess of soils (Das et al., 1997). Ghosh and Mukhopadhyay (1996) also revealed that the total $\mathrm{K}$ has highly positive and significant correlation with silt and clay fraction of soil indicating that substantial quantities of $\mathrm{K}$ bearing minerals are present in silt and clay fractions of the soils under investigation. Sharma et al., (2006) found that total potassium was high in clay soil which shows that among the various particle-size fractions, clay is a principal host of $\mathrm{K}$ in these soils. Total potassium was positively correlated with CEC in soils while water soluble was negatively correlated with CEC and clay content in the soil. They also reported 
significant positive correlation between $\mathrm{pH}$ and total potassium and highly significant negative relationship of total potassium with clay, which is attributed mainly to a higher proportion of potassium rich minerals in silt fractions and feldspars are known to occur mainly in 2 to $50 \mu$ fractions (Koria et al., 1989). Adhikari and Ghosh, (1991) observed an increase in total potassium content of different size fractions with increase in particle size.

\section{References}

Adhikari, M. and Ghosh, T. K. 1991. Potash reserves and quantity/intensity relationships of different soils of West Bengal. J Pot Res 7: 161-169

Ahmed, N. and Walia, C. S. 1999. Profile distribution of various forms of potassium in some landforms of Bundelkhand region. J Pot Res 15: 1-4.

Baruah, H. C. and Nath, A. K. 1992. Potassium status in three major soils of Assam. J Indian Soc Soil Sci 40: 559561.

Baruah HC, Bora DK, Baruah T C and Nath A K (1991) Fixation of potassium in three major soil orders of Assam. J Pot Res 7(3): 170-75.

Basumatary, A. and Bordoli, P. K. 1992. Forms of potassium in the soils of Assam in relation to soil properties. $J$ Indian Soc Soil Sci 40: 443-446.

Darunsontaya, T., Suddhiprakarn, A., Kheoruenromne, I., Prakongkep, N. and Gilkes, R. J. 2012. The forms and availability to plants of soil potassium as related to mineralogy for upland oxisols and utisols from Thailand. Geoderma 170: 11-24.

Das, K., Singh, S. K. and Shyampura, R. L. 1993. Forms of $\mathrm{K}$ in relation to land form and soil properties of Basaltic terrian. J Indian Soc Soil Sci 41: 557559.
Das, P. K., Sahu, G. S. and Das, N. 1997. Vertical distribution and release characteristics of potassium in some lateritic soils of Orissa. J Pot Res 13: 105-110.

Dhakad, H., Yadav, S. S., Jamra, S., Arya, V., Sharma, K. and Gaur, D. 2017. Status and distribution of different forms of potassium in soils of Gwalior District (M.P.). Int J chem Studies 5(5): 161164.

Dhillon, S. K., Sidhu, P. S., Dhillon, K. S. and Sharma, Y. P. 1985. Distribution of various potassium forms in some benchmark soils of North-West India. J Pot Res 1: 154-165.

Dixit, A. K., Sachan, R. S., Srivastava, P. C. and Mishra, M. K. 1993. Distribution of different forms of potassium in some soil series of western U.P. J Pot Res 9: 295-314.

Ganeshamurthy, A. N. and Biswas, C. R. 1985. Contribution of potassium from non-exchangeable sources in soil to crops. J Indian Soc Soil Sci 33: 60-66.

Ghiri, M. N. and Abtahi, A. 2011. Potassium dynamics in calcareous vertisols of Southern Iran. Arid Land Res Manag 25: 257-274.

Ghosh, B. N. and Mukhopadhyay, A. K. 1996. Potassium release characterisitics of some soils of West Bengal and their relationship with forms of soil $\mathrm{K}$ and clay mineralogy. Geoderma 104: 135144.

Grewal, J. S. and Kanwar, J. S. 1973. Potassium fixation in some soils of Punjab, Haryana and Himachal. J Ind Soc Soil Sci 15: 237-244.

Guzel, N., Buyuk, G. and Ibrikei, H. 2006. Non-exchangeable and exchangeable potassium status of soils in relation to clay mineralogy and other soil properties in Hilvan area of upper Mesopotamia in southeastern Anatolia. Commun Soil Sci Pl Anal 32: 2877- 
2892.

Jatav, M. K. and Sud, K. C. 2006. Distribution of different forms of potassium in potato growing soils of Shimla district. Potato J 33: 176-178.

Koria, R.G., Patil, M. S. and Yadav, B. S. 1989. Vertical distribution of forms of potassium in some soil profiles of dry farming areas of Sawrashtra region in Gujarat. J Pot Res 5(2): 47-52.

Kundu, M. C., Hazra, G. C., Biswas, P. K., Mondal, S. and Ghosh, G. K. 2014. Forms and distribution of potassium in some soils of Hooghly district of West Bengal. J Crop Weed 10: 31-37.

Martin, H.W. and Sparks, D. L. 1983. On the behavior of Nonexchangeable potassium in soils. Commun Soil Sci Plant Anal 16: 133-162.

Mishra, M. K., Srivastava, P. C. and Ghosh, D. 1993. Forms of potassium in relation to soil properties and clay mineralogy in some soils of Chambal command area, Rajasthan. J Pot Res 9: 87-94.

Mukhopadhyay, S. S. and Datta, S. C. 2001. Potassium availability in relation to soil mineralogy in the Indo-Gangetic Plains. pp 33-44. In: Proceedings of Potassium in Indian agriculture. International Potash Institute. Gurgaon, India.

Mengel, K. and Haeder, H. E. 1973. Binding sites for potassium on 2:1 clay minerals such as illite, vermiculite and chlorite. Potash Rev 11: 1-8.

Nagarajan, P. S. 1980. Evaluation of selected soil test methods and crop response studies for $K$ with rice. M.Sc. Thesis, TNAU, CBE, India.

Ngwe, K., Kheoruenromne, I. and Suddhiprakarn, A. 2012. Potassium status and physicochemical and mineralogical properties of lowland vertisols in a rice-based cropping system under tropical savanna climate.
Kasetsart J Nat Sci 46: 522-537.

Pal, S. K. and Mukhopadhyay, A. K. 1992. Distribution of different forms of potassium in profiles of some Entisols. J Indian Soc Soil Sci 40: 371-373.

Pasricha, N. S. 2002. Potassium dynamics in soils in relation to crop nutrition. $J$ Indian Soc Soil Sci 50(4): 333-344.

Perkins, A. H. F. 1973. Potassium fixation and reconstitution of micaceous structures in soil. Soil Sci 116: 31-35.

Ramamoorthy, B. and Velayutham, M. 1976. $N, P \& K$ in soil - chemistry, form \& availability in soil fertility. Theory \& practice compiled \& edited by J.S. Kanwar, I.C.A.R., New Delhi, India

Ramanathan, K. M. 1978. An evaluation of potassium availability indices of some soils of South India. J Indian Soc Soil Sci 26: 198-202..

Ranganathan, P. and Satyanarayana, T. 1980. Studies on potassium status of soils of Karnataka. J Indian Soc Soil Sci 28: 148-153.

Schroeder, D. 1974. Potassium research and Agrl production. Proc 10th cong. pp 53-63.International Potash Institute.

Sharma, A., Jalali, V.K., Arya, V. M. and Pradeep, R. 2009. Distribution of Various Forms of Potassium in Soils Representing Intermediate Zone of Jammu Region. J Indian Soc Soil Sci 57(2): 205-207

Sharma, B. D., Mukhopadhyay, S.S. and Sawhney, J. S. 2006. Distribution of potassium fractions in relation to landforms in a Himalayan catena. Arch Agron Soil 52: 469-476.

Sharpley, A. N. 1989. Relationship between soil potassium forms and mineralogy. Soil Sci Soc Am J 52: 1023-1028.

Sidhu, P. S. and Dhillon, S. K. 1985. Mineralogy of potassium in some typical soils of Punjab. J Pot Res 1: 17-27.

Singh, Y.P., Singh, M. and Singh, R. 1985. 
Forms of soil potassium in Western part of Haryana. J Indian Soc Soil Sci 35(2): 284-291.

Sparks, D. L. 1987. Potassium Dynamics in soils. Adv Soil Sci 6: 1-63.

Sparks, D.L. and Huang, P.M. 1985. Physical Chemistry of Soil Potassium. In: Munson R D (Eds.) Potassium in Agriculture, Agronomy Society of America, Soil Science Society of America, Madison, Wisconsin, USA, pp. 201-76.

Srinivasarao, C. and Takkar, P. N. 1997. Evaluation of different extractants for measuring the soil potassium and determination of critical levels for plant available $\mathrm{K}$ in smectitic soils for sorghum. J Pl Nutr Soil Sci 160(1): 103-107.

Srinivasarao, C., Vittal, K. P. R., Tiwari, K. N., Gajbhiye, P. N., Kundu, S., Pharande, A. L., Reddy, Y. Y. and Shankar, M. A. 2007. Potassium supplying characteristics of twenty one soil profiles under diverse rainfed production systems. J Indian Soc Soil Sci 55: 14-22.

Tandon, H. C. S. and Sekhon, G. S. 1998. K research and agricultural production in India. Publications from fertilizer development and consultation organization in New Delhi. India.

\section{How to cite this article:}

Harpreet Kaur. 2019. Forms of Potassium in Soil and their Relationship with Soil Properties- A Review. Int.J.Curr.Microbiol.App.Sci. 8(10): 1580-1586.

doi: https://doi.org/10.20546/ijcmas.2019.810.184 